Check for updates

The BMJ

fgodlee@bmi.com Follow Fiona on Twitter@fgodlee

Cite this as: BMJ2021:374:n1662 http://dx.doi.org/10.1136/bmj.n1662 Published: 1 July 2021

\title{
Dear Sajid Javid: open letter to a new minister of health
}

\section{Fiona Godlee editor in chief}

Dear secretary of state,

You arrive at a crucial time in the pandemic and have the chance to shake off past mistakes and do things differently (doi:10.1136/bmj.n1649). ${ }^{1}$ We suggest 10 urgent actions.

- Abandon mass asymptomatic testing. The UK's testing strategy adopted a poorly performing test and has used it badly, squandering precious funds, failing to contain the virus, and damaging public trust (doi:10.1136/bmj.n1636). ${ }^{2}$ Instead we should move to targeted testing of people most at risk (doi:10.1136/bmj.n1638). ${ }^{3}$

- Establish proper financial support for those who need to isolate. Testing works only if people are willing to be tested and can act on the results. The government's unwillingness to help people isolate is a fatal flaw

(https://blogs.bmj.com/bmj/2021/o6/29/after-restriction-why-the-public-can-only-fulfill-its-responsibilities-if-the-government-fulfills-theirs). ${ }^{4}$

- Provide messaging that is up to date and based on evidence. The public are understandably confused about testing, especially in light of the delta variant's different set of symptoms (doi:10.1136/bmj.n1654). ${ }^{5}$

- Invest in ventilation. The virus is airborne and good ventilation is key, especially in schools, healthcare settings, workplaces, restaurants, and bars (doi:10.1136/bmj.n913). ${ }^{6}$ Other countries have invested in upgrading buildings or installing $\mathrm{CO}_{2}$ monitors and air purifiers

(https://blogs.bmj.com/bmj/2021/o6/28/use-ofairborne-precautions-for-covid-19-in-healthcaresettings). ${ }^{7}$

- Make FFP3 masks mandatory for all staff treating patients with suspected or confirmed covid. Staff should not be put at risk by their work. Shortages of personal protective equipment (PPE) and erroneous guidance led to avoidable illness and death and continue to contribute to staff absence and burnout. New information confirms the protective effect of proper PPE (doi:10.1136/bmj.n1663). ${ }^{8}$

- Share vaccines with the world. The World Health Organization has said that vaccinating under $18 \mathrm{~s}$ is not a priority (https://www.who.int/directorgeneral/speeches/detail/director-general-s-opening-remarks-at-the-media-briefing-on-covid-1914-may-2021). ${ }^{9}$ Instead, to help end the pandemic and prevent new variants emerging we should ensure that vaccines are available and affordable to poorer countries and vulnerable populations (doi:10.1136/bmj.n1444; doi:10.1136/bmj.n16o8). ${ }^{10} 11$
- Establish an urgent review of workforce planning, with funding for recruitment, training, and retention of staff. Staff were at full stretch before the pandemic. They are now in large part exhausted and demoralised (doi:10.1136/bmj.n1603). ${ }^{12}$

- Ensure a long term settlement for health and social care (doi:10.1136/bmj.n1555). ${ }^{13}$ The current plan was agreed before the pandemic and won't be enough to tackle waiting lists (doi:10.1136/bmj.n1497; doi:10.1136/bmj.n1616), long term symptoms of covid (doi:10.1136/bmj.n1626), winter pressures, or preparing for the next pandemic. ${ }^{14-16}$

- Act on the social determinants of health. Social inequalities and poor underlying health were a major cause of the UK's high rates of death and illness during the pandemic (doi:10.1136/bmj.n1677; https://blogs.bmj.com/bmj/2021/06/30/michaelmarmot-and-jessica-allen-building-back-fairer-in greater-manchester). ${ }^{17} 18$

- Appoint the next head of NHS England through a transparent and competitive process. Simon Stevens will be a hard act to follow.

lacobucci G. Hancock resigns after covid guideline breach and Sajid Javid becomes new health secretary. BM/2021;373:n1649. doi: 10.1136/bmi.n1649 pmid: 34183382

2 Torjesen I. NHS Test and Trace: lack of progress is "deeply disappointing". BM/2021;373:n1636. doi: 10.1136/bmj.n1636 pmid: 34167940

3 Rae M. The government must support communities across the UK to tackle covid-19 long term. BM/2021;373:n1638. doi: 10.1136/bmj.n1638 pmid: 34183328

4 Reicher S, Michie S, Phoenix A. After restriction: why the public can only fulfill its responsibilities if the government fulfills theirs. BMJ Opinion. 29 Jun 2021. https://blogs.bmi.com/bmi/2021/06/29/after-restriction-why-thepublic-can-only-fulfill-its-responsibilities-if-the-government-fulfills-theirs.

5 Mahase E. Covid-19: GPs urge government to clear up confusion over symptoms. BM/2021;373:n1654. doi: 10.1136/bmj.n1654 pmid: 34183357

6 Tang JW, Marr LC, Li Y, Dancer SI. Covid-19 has redefined airborne transmission. BMJ2021;373:n913. doi: 10.1136/bmj.n913 pmid: 33853842

7 Lawton L, Butler M, Peters C, et al. Use of airborne precautions for covid-19 in healthcare settings. BMJ Opinion. 28 Jun 2021. https://blogs.bmi.com/bmi/2021/06/28/use-of-airborne-precautions-forcovid-19-in-healthcare-settings.

8 Wise J. Covid-19: Upgrading to FFP3 respirators cuts infection risk, research finds. BM/2021;373:n1663doi: 10.1136/bmi.n1663.

9 Director-general's opening remarks at the media briefing on covid-19-14 May 2021. World Health Organization. 2021. https://www.who.int/directorgeneral/speeches/detail/director-general-s-opening-remarks-at-the-mediabriefing-on-covid-19-14-may-2021.

10 Mahase E. Covid-19: Freedom won't last if UK doesn't share excess vaccine doses, aid agencies warn. BMJ2021;373:n1444. doi: 10.1136/bmj.n1444 pmid: 34088730

11 Teerawattananon Y, Teo YY, Lim JFY, Hsu LY, Dabak S. Vaccinating undocumented migrants against covid-19. BMJ2021;373:n1608. doi: 10.1136/bmj.n1608 pmid: 34172456

12 Bailey S. Parliamentary report on workforce burnout and resilience. BMJ 2021;373:n1603. doi: 10.1136/bmi.n1603 pmid: 34168000

13 Murray R. The NHS needs a comprehensive plan for recovery. BMJ 2021:373:n1555. doi: 10.1136/bmj.n1555 pmid: 34144969 
14 Limb M. Waiting list for hospital treatment tops "grim milestone" of five million. BMJ 2021;373:n1497. doi: 10.1136/bmj.n1497 pmid: 34112650

15 Oxtoby K. Covid-19: "Life on hold” for NHS patients needing musculoskeletal care. BMJ 2021;373:n1616doi: 10.1136/bmj.n1616.

16 O’Dowd A. Covid-19: Third of people infected have long term symptoms. BM/2021;373:n1626 doi: 10.1136/bmj.n1626 pmid: 34168002

17 Mahase E. Covid-19: Government must tackle stark regional health inequalities exposed by pandemic, says Marmot. BMJ 2021;373:n1677.

18 Marmot M, Allen J. Building back fairer in Greater Manchester. BMJ Opinion. 30 Jun 2021 https://blogs.bmj.com/bmj/2021/06/30/michael-marmot-and-jessica-allen-building-back-fairerin-greater-manchester.

This article is made freely available for use in accordance with BMJ's website terms and conditions for the duration of the covid-19 pandemic or until otherwise determined by BMJ. You may use, download and print the article for any lawful, non-commercial purpose (including text and data mining) provided that all copyright notices and trade marks are retained. 